\title{
Mechanism of antinociceptive action of syringic acid
}

\author{
Mehmet Evren OKUR 1* iD, Ayşe Arzu ŞAKUL 2 (iD \\ 1 Department of Pharmacology, Faculty of Pharmacy, University of Health Sciences, Istanbul, Turkey. \\ 2 Department of Medical Pharmacology, School of Medicine, Istanbul Medipol University, Istanbul, Turkey. \\ * Corresponding Author. E-mail: evrenokurecz@gmail.com (M.E.O.); Tel. +90-216-418 9616.
}

Received: 31 January 2021 / Revised: 23 March 2021/ Accepted: 24 March 2021

\begin{abstract}
Syringic acid presents various biological properties such as antioxidant, anti-inflammatory, anticancer, and other activities. The present experiment aimed to investigate the effect of the oral administration of syringic acid $(10,50$, and $100 \mathrm{mg} / \mathrm{kg})$ on its possible nociceptive response using hot-plate and tail-flick assay in the Balb-C mice model. The mice were pre-treated with $5 \mathrm{mg} / \mathrm{kg}$ atropine $15 \mathrm{~min}$ before, $1 \mathrm{mg} / \mathrm{kg}$ mecamylamine $20 \mathrm{~min}$ before, $1 \mathrm{mg} / \mathrm{kg}$ ketanserin $30 \mathrm{~min}$ before, $1 \mathrm{mg} / \mathrm{kg}$ ondansetron $30 \mathrm{~min}$ before, $1 \mathrm{mg} / \mathrm{kg}$ yohimbine $30 \mathrm{~min}$ before, $1 \mathrm{mg} / \mathrm{kg}$ prazosin 30 $\mathrm{min}$ before and $5 \mathrm{mg} / \mathrm{kg}$ naloxone $15 \mathrm{~min}$ before the administration of the Syringic acid. Dose-dependent antinociceptive activity of syringic acid was reported for 50 and $100 \mathrm{mg} / \mathrm{kg}$ doses in tail-flick and hot-plate assays, respectively. In further, mecamylamine, yohimbine, and naloxone significantly reversed syringic acid-induced response to thermal stimuli in tail-flick and hot-plate assays, respectively. From the data, it was confirmed that syringic acid presents central antinociceptive effects which may be coordinated by supraspinal/spinal mediated cholinergic, opioidergic, and adrenergic, inflection.
\end{abstract}

KEYWORDS: Antinociception; muscarinic receptors; opioidergic receptors; a 2 -adrenoceptors; syringic acid.

\section{INTRODUCTION}

Pain relief management is a very significant factor for clinical practice since pain especially in a chronic state can affect a patient's life. Pain has been associated with tissue injury and its alleviation can improve human conditions or general animal welfare $[1,2]$. Therefore, several biomedical and research methodologies have been introduced in order to understand and explore the possible mechanisms involving pain. Besides this, novel drug candidates that can decrease pain are also designed with interesting analgesic properties [35]. Nonetheless, there still an urgent need for developing novel analgesics for better pain relief. In order to study the mechanisms of pain and analgesia, numerous animal models have been employed and found to be effective [6,7]. Besides, preclinical studies are essential for drug development and design [8].

It was stated that nociception provides neural feedback which enables the central nervous system to detect and avoid noxious and potentially damaging stimuli [9]. Normally, nociception and pain can be promoted at specific conditions such as extreme pressure and/or temperature which can be harmful to tissues. Moreover, toxic compounds and inflammatory mediators may also evoke nociception and pain [10]. The aforementioned physical or chemical stimuli when taking place, are being detected from specific peripheral sensory neurons known as nociceptors. In general, the pain has been described to present various qualities and temporal properties which are dependent on the stimulus modality and locality $[10,11]$.

Four significant forms of pain have been identified and classified as acute pain, nociceptive pain, chronic pain, and neuropathic pain. Nociceptors are being triggered by acute noxious stimuli such as heat or cold temperatures, mechanical force, or chemical stimulation; nociceptive pain normally arises when the tissues are being damaged due to physical or chemical agents i.e. trauma, surgery, or chemical burns [12-14]. Thus, drugs with antinociceptive properties can be helpful in clinical practice.

Syringic acid (Figure 1), also chemically known as 4-hydroxy-3,5-dimethoxybenzoic acid, is a widespread phenolic compound found in natural sources as plants. It presents various biochemical properties such as antimicrobial, anti-inflammatory, antioxidant activities. In addition, it has been suggested as a cardioprotective and protective agent for the liver and brain/central nervous system [15-17]. The role of syringic acid in inhibiting neurodegenerative progress is improved due to its ability of crossing the bloodbrain barrier. Syringic acid has been generally used in clinical practice and the industrial sector [15]. According

How to cite this article: Okur ME, Şakul AA. Mechanism of antinociceptive action of the syringic acid. J Res Pharm. 2021; 25(3): 277-286. 
to the published reports, syringic acid has been demonstrated to reduce pain in acute pancreatitis and several plant extracts with syringic acid have been found to be effective in alleviating pain [18-20].

Herein, we report the possible antinociceptive properties of syringic acid; in the past, a derivative of SA, known as syringin was studied along with sinapyl alcohol [21]. As a result, the purpose of this research was to explore and compare the antinociceptive effects of syringic acids on hot-plate and tail-flick assays in an in vivo model.<smiles>COc1cc(C(=O)O)cc(OC)c1O</smiles>

Figure 1. Chemical structure of syringic acid.

\section{RESULTS}

\subsection{Antinociceptive effect of syringic acid}

Figure 2 presents the antinociceptive effects of syringic acid according to hot-plate and tail-flick assays. Accordingly, it can be seen that diclofenac used as the reference drug, significantly hindered the pain response in comparison with the control group. This significant inhibition of pain response was recorded for both hotplate $(p<0.001)$ and tail-flick $(p<0.001)$ tests. Moreover, the application of syringic acid at doses of 10,50 $(\mathrm{p}<0.05)$, and $100 \mathrm{mg} / \mathrm{kg}(\mathrm{p}<0.05)$ induced a notable as well as a dose-dependent increment in the mean basal reaction time in hot-plate and tail-flick tests, in comparison with the control group. Consequently, the obtained data clearly demonstrated that oral administration of $100 \mathrm{mg} / \mathrm{kg}$ of syringic acid was remarkably more efficacious than the application of lower doses $(10,50 \mathrm{mg} / \mathrm{kg})$ of syringic acid and the control group as well.

\subsection{Evaluation of the mechanism of antinociceptive action of syringic acid}

\subsubsection{Role of the cholinergic mechanisms in the antinociceptive effect of syringic acid}

As shown in Figure 3, atropine ( $5 \mathrm{mg} / \mathrm{kg}$, i.p) had no significant analgesic activity in both tail-flick and hot-plate tests. Syringic acid $(\mathrm{p}<0.05)$ and syringic acid plus atropine $(\mathrm{p}<0.05)$ showed a significant effect on pain response as compared to the control group. On the other hand, intraperitoneal injection of atropine slightly decreased antinociceptive activity of syringic acid $(100 \mathrm{mg} / \mathrm{kg})$ in the hot-plate test but that change was not statistically significant.

As seen in Figure 4, a single administration of mecamylamine $(1 \mathrm{mg} / \mathrm{kg}$, i.p.) was failed to show significance compared to the control group. Importantly, intraperitoneal pre-treatment with $1 \mathrm{mg} / \mathrm{kg}$ mecamylamine significantly reversed the antinociceptive action of syringic acid $(100 \mathrm{mg} / \mathrm{kg})$ in the hot-plate $(\mathrm{p}<0.01)$ and tail-flick $(\mathrm{p}<0.01)$ tests in comparison with the syringic acid alone.

\subsubsection{Role of the serotonergic mechanisms in the antinociceptive effect of syringic acid}

In order to clarify the effect of ketanserin treatment on tail-flick and hot-plate tests, a single administration of ketanserin $(1 \mathrm{mg} / \mathrm{kg}$ ) caused no significant difference in antinociceptive response (Figure 5). The results indicate that ketanserin did not revert the antinociceptive effect observed for syringic acid in a significant way.

As depicted in Figure 6, the administration of intraperitoneal injection of $5 \mathrm{mg} / \mathrm{kg}$ ondansetron neither affected the nociceptive response nor modified the antinociceptive activity of syringic acid $(100 \mathrm{mg} / \mathrm{kg})$ in the hot-plate and tail-flick assays. Moreover, ondansetron pre-treatment did not significantly decrease in latency of the syringic acid-mediated analgesic responses in the hot-plate and tail-flick tests.

\subsubsection{Role of the adrenergic mechanisms in the antinociceptive effect of syringic acid}

Figure 7 shows that pre-treatment with prazosin $(5 \mathrm{mg} / \mathrm{kg}$, i.p.) itself did not exert any antinociceptive effects in both hot-plate and tail-flick tests. The pre-treatment with prazosin did not reduce the syringic acidinduced acute thermal antinociceptive effect in the hot-plate or tail-flick tests. 

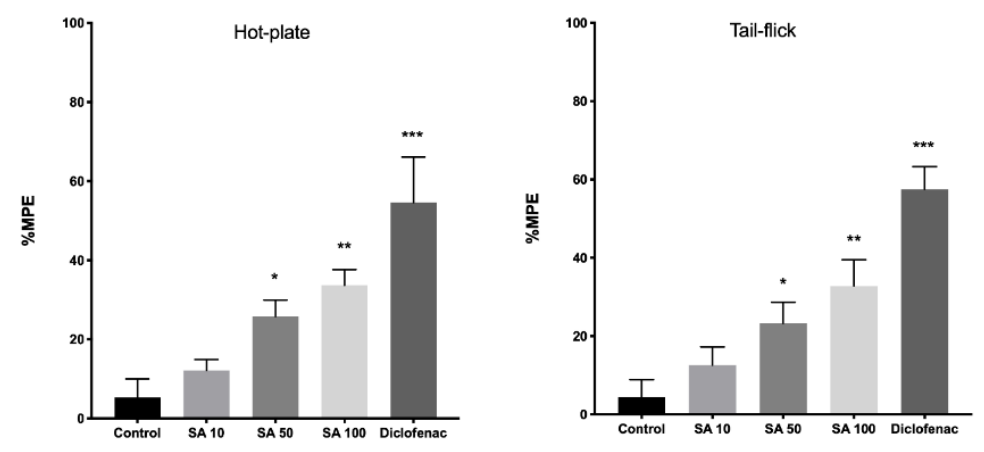

Figure 2. Antinociceptive effects of 10, 50, and $100 \mathrm{mg} / \mathrm{kg}$ (p.o.) syringic acid and $25 \mathrm{mg} / \mathrm{kg}$ diclofenac (p.o.) on the hot-plate and tail-flick assays. Statistically significant difference; ${ }^{*} \mathrm{p}<0.05,{ }^{* *} \mathrm{p}<0.01,{ }^{* * *} \mathrm{p}<0.001$ vs. control. Data are expressed as mean \pm SEM. MPE: Maximal possible antinociceptive effect.
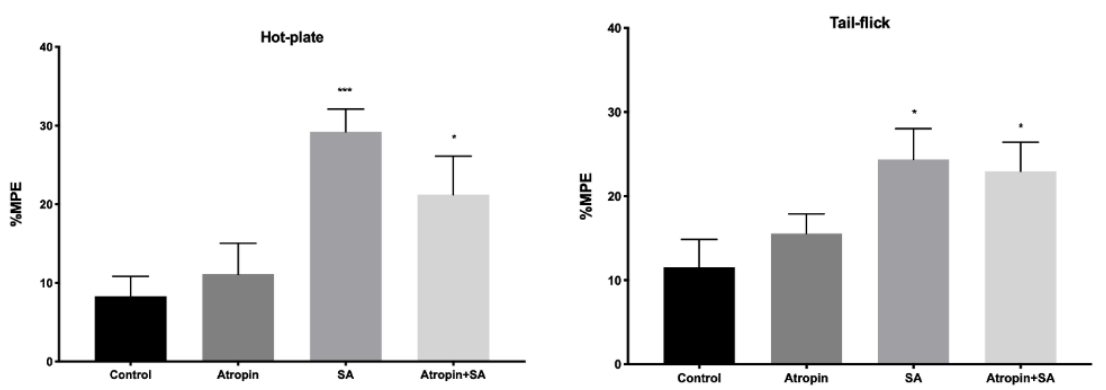

Figure 3. Effects of $5 \mathrm{mg} / \mathrm{kg}$ atropine (ip) on the antinociceptive activity of $100 \mathrm{mg} / \mathrm{kg}$ syringic acid (po) in the hot-plate and tail-flick assays. Statistically significant difference; ${ }^{*} p<0.05,{ }^{* * *} \mathrm{p}<0.001$ vs. control. Data are expressed as mean \pm SEM. MPE: Maximal possible antinociceptive effect.
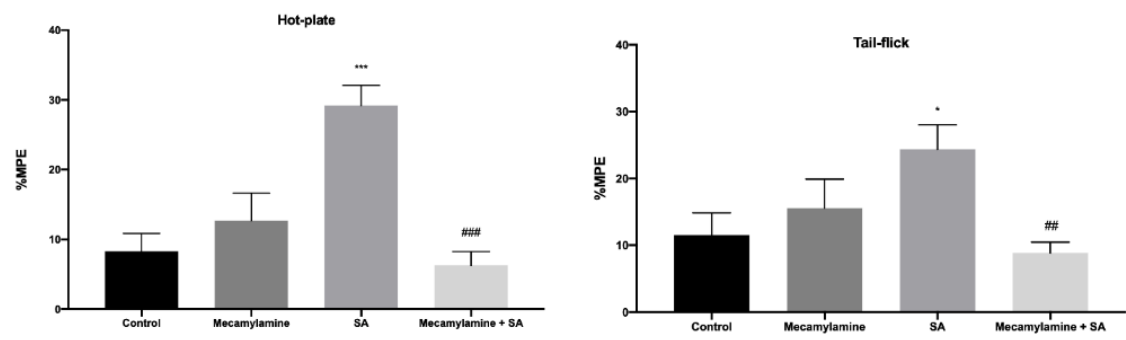

Figure 4. Effects of $1 \mathrm{mg} / \mathrm{kg}$ mecamylamine (ip) on the antinociceptive activity of $100 \mathrm{mg} / \mathrm{kg}$ syringic acid (po) in the hot-plate and tail-flick assays. Statistically significant difference; ${ }^{*} \mathrm{p}<0.05,{ }^{* * *} \mathrm{p}<0.001$ vs. control; $\#$ p $<0.01$ vs. syringic acid alone. Data are expressed as mean \pm SEM. MPE: Maximal possible antinociceptive effect.
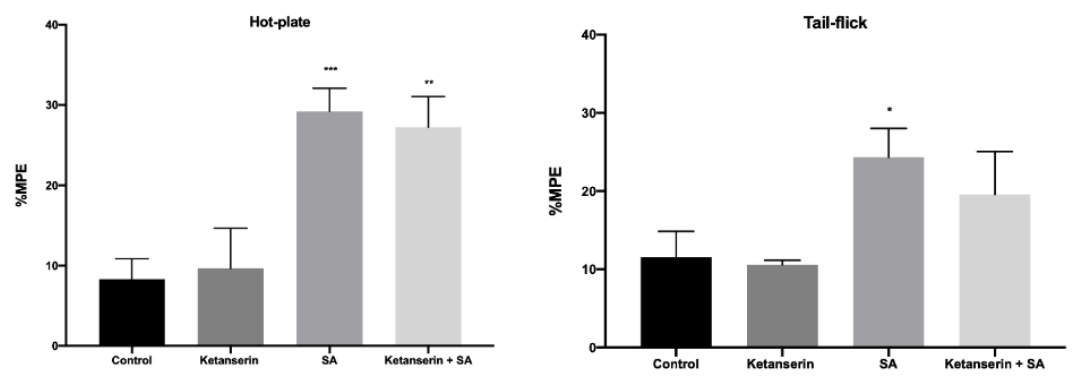

Figure 5. Effects of $1 \mathrm{mg} / \mathrm{kg}$ ketanserin (ip) on the antinociceptive activity of $100 \mathrm{mg} / \mathrm{kg}$ syringic acid (po) in the hot-plate and tail-flick assays. Statistically significant difference; ${ }^{*} \mathrm{p}<0.05,{ }^{* *} \mathrm{p}<0.01,{ }^{* * *} \mathrm{p}<0.001$ vs. control. Data are expressed as mean \pm SEM. MPE: Maximal possible antinociceptive effect. 

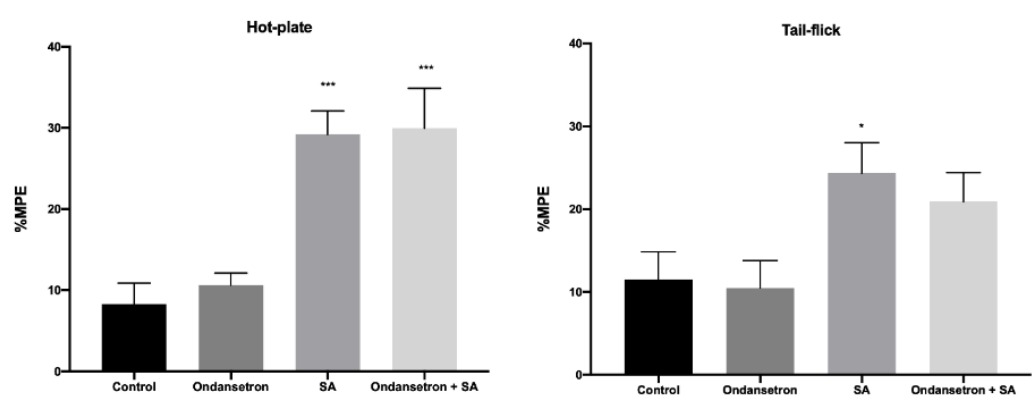

Figure 6. Effects of $5 \mathrm{mg} / \mathrm{kg}$ ondansetron (ip) on the antinociceptive activity of $100 \mathrm{mg} / \mathrm{kg}$ syringic acid (po) in the hot-plate and tail-flick assays. Statistically significant difference; ${ }^{*} p<0.05,{ }^{* * *} p<0.001$ vs. control. Data are expressed as mean \pm SEM. MPE: Maximal possible antinociceptive effect.
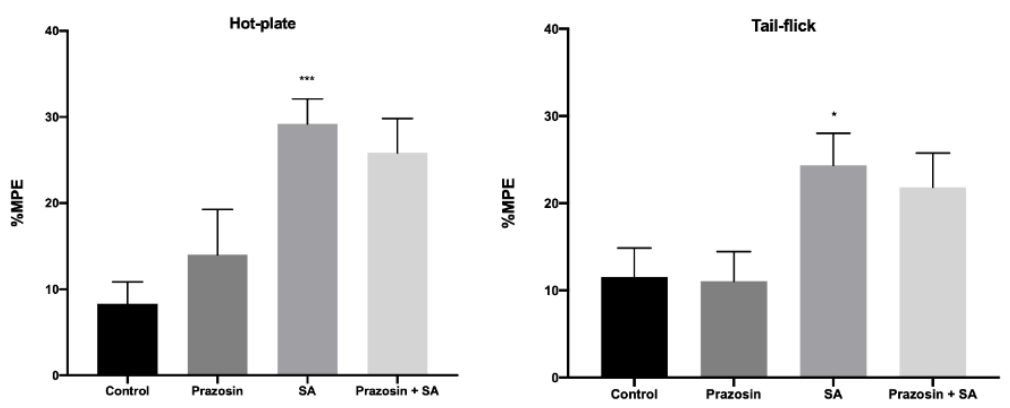

Figure 7. Effects of $5 \mathrm{mg} / \mathrm{kg}$ prazosin (ip) on the antinociceptive activity of $100 \mathrm{mg} / \mathrm{kg}$ syringic acid (po) in the hot-plate and tail-flick assays. Statistically significant difference; ${ }^{*} \mathrm{p}<0.05,{ }^{* * *} \mathrm{p}<0.001 \mathrm{vs}$. control. Data are expressed as mean \pm SEM. MPE: Maximal possible antinociceptive effect.

According to Figure 8 , yohimbine $(1 \mathrm{mg} / \mathrm{kg}$, i.p.) was revealed to neither attenuate nor potentiate the antinociceptive actions in the mouse tail-flick and hot-plate assays. More specifically, i.p. administration of yohimbine $(1 \mathrm{mg} / \mathrm{kg})$ demonstrated a significant reduction on the antinociceptive activity of syringic acid in hot-plate $(\mathrm{p}<0.001)$ and tail-flick $(\mathrm{p}<0.01)$ analyses, in comparison with the syringic acid $(100 \mathrm{mg} / \mathrm{kg})$ alone.

\subsubsection{Role of the opioidergic mechanisms in the antinociceptive effect of syringic acid}

Figure 9 depicts the involvement of opioid receptors in the antinociceptive effects of syringic acid assessed using hot-plate and tail-flick tests, respectively. The results in Figure 9 show that the treatment of mice with naloxone $(5 \mathrm{mg} / \mathrm{kg}$, i.p.) did not significantly alter the latency response in the hot-plate and tail-flick tests. On the other hand, the pre-treatment with naloxone, the non-selective opioid antagonist significantly blocked syringic acid-induced antinociception in the hot-plate $(\mathrm{p}<0.001)$ and tail-flick $(\mathrm{p}<0.01)$ tests in comparison with syringic acid alone.

\section{DISCUSSION}

In the present study, extensive research for the possible central antinociceptive effects of syringic acid using various pharmacological approaches, such as hot-plate test and tail-immersion test, was performed. Although the tail-flick reflex is a spinally organized response, the hot-plate model is considered a central reflex and is an interesting model for evaluating supra-spinal-acting drugs [22]. It can be generally concluded that syringic acid reveals statistically significant antinociceptive properties of the treated mice compared with the control treated mice group. Moreover, it can be suggested that the antinociceptive effects as demonstrated by the hot-plate and tail-immersion assays, were mostly arranged by spinal and supraspinal-mediated opioidergic, cholinergic, and adrenergic systems.

A previous study reported that syringic acid application $(1000 \mathrm{mg} / \mathrm{kg} /$ day, p.o for 14 days $)$, did not induce any side effects on the body weight, food intake, erythropoiesis, leucopoiesis as well as internal body organs. The obtained results were confirmed through the evaluation of several biochemical and hematological parameters, relative body organ weight, and histopathological studies [23]. 

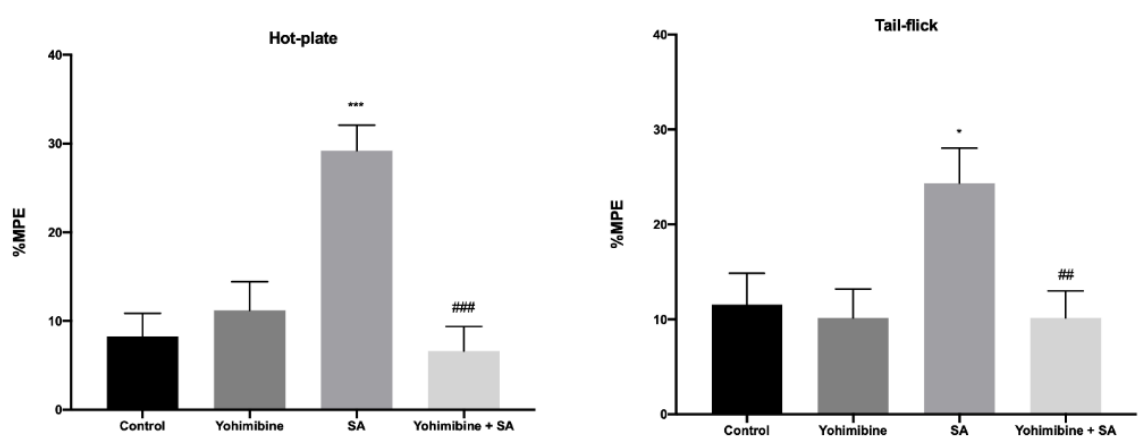

Figure 8. Effects of $1 \mathrm{mg} / \mathrm{kg}$ yohimbine (ip) on the antinociceptive activity of $100 \mathrm{mg} / \mathrm{kg}$ syringic acid (po) in the hot-plate and tail-flick assays. Statistically significant difference; ${ }^{*} \mathrm{p}<0.05,{ }^{* * *} \mathrm{p}<0.001$ vs. control; $\# \# p<0.01$, \#\#\# $<0.001$ vs. syringic acid alone. Data are expressed as mean \pm SEM. MPE: Maximal possible antinociceptive effect.
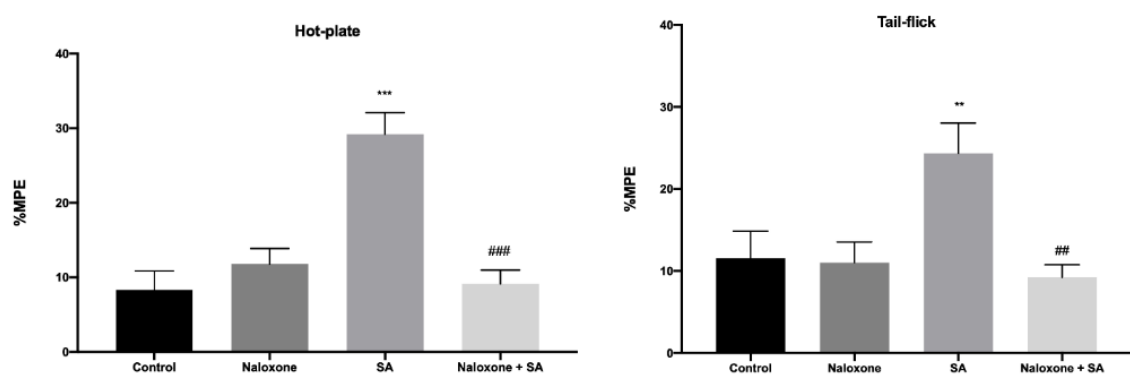

Figure 9. Effects of $5 \mathrm{mg} / \mathrm{kg}$ naloxone (ip) on the antinociceptive activity of $100 \mathrm{mg} / \mathrm{kg}$ syringic acid (po) in the hot-plate and tail-flick assays. Statistically significant difference; ${ }^{* *} p<0.01,{ }^{* * *} p<0.001$ vs. control; ${ }^{\# \#} p<0.01$, $\# \#$ p $<0.001$ vs. syringic acid alone. Data are expressed as mean \pm SEM. MPE: Maximal possible antinociceptive effect.

In the literature, it has been said that acetylcholine which is a neurotransmitter of the central nervous system, acts in pain transmission [24]. In further, muscarinic receptors are being activated and induce the various modulators release as well as the permeability of numerous ion channels. These channels and modulators mostly control the transmission of pain. Several types of researches, involving animal experimental procedures, have reported the analgesic activity of cholinergic agonists by inducing the cholinergic pathway through the activation of muscarinic receptors [25]. However, in this research, the atropine application was not capable of attenuating the antinociceptive activity of syringic acid, pointing to the absence of the muscarinic system participation, in syringic acid effects.

Moreover, last decades, the pharmacological involvement of nicotinic cholinergic receptors for pain management, has been thoroughly studied. It has been demonstrated that the aforementioned receptors are widely expressed in the central and peripheral nervous system as well as in the immune cells. Consequently, pharmacological drugs like recent $\alpha_{4} \beta_{2}$ nicotinic receptor agonists are being produced the controlling the pain [26]. The reduction of pain signal neurotransmission in the spinal cord is stimulated by the activation of descending inhibitory mechanisms, of supraspinal and midbrain a $4 \beta 2$ nicotinic acetylcholine receptors activates [27]. From the above, it can be suggested that the antinociceptive effect of syringic acid as studied through hot-plate and tail-flick assays was significantly antagonized by the pre-treatment with mecamylamine. Mecamylamine is a known nicotinic acetylcholine receptor antagonist. Subsequently, the antinociceptive activity of syringic acid could be organized by spinal and supraspinal mediated nicotinic acetylcholine receptors.

It has been reported that inhibitory descending pathways modulate pain perception as the main neurotransmitter involved serotonin has been suggested. Thus, the inhibition of pain transmission mediated via serotonin seems to be promoted from the aforementioned descending routes composing the raphe nuclei toward the dorsal horn of the spinal cord [24]. Consequently, the serotonergic system and serotonin receptors 
have been identified as therapeutic targets in order to pain management. For example, the application of antidepressants in pain management has been based on the suggested approach [28]. In this study, the potent analgesic mechanism of syringic acid was studied after ketanserin and ondansetron administration to mice. The specific drugs were used in order to assess their inhibitory effect on the analgesic activity of the syringic acid. The obtained data demonstrated that the antinociceptive activity of syringic acid is not related to 5$\mathrm{HT}_{2 \mathrm{~A} / 2 \mathrm{C}}$ or $5-\mathrm{HT}_{3}$ serotonergic receptors.

Furthermore, it has been reported that the perception of pain could be associated with the noradrenergic neurons in the locus ceruleus mediate analgesia through axon terminals in the spinal dorsal cord. Therefore, many alpha noradrenergic receptor agonist drugs (i.e. dexmedetomidine and clonidine) have shown analgesic activity [29]. In this study, prazosin did not influence the analgesic effect of the syringic acid demonstrating the absence of $a_{1}$ adrenergic participation in the syringic acid activity. Besides, it has been reported that the application of $a_{2}$-adrenoceptor agonists might produce anti-nociception in rodents. This effect could be associated with the inhibition of synaptic transmission in the dorsal horn of the spinal cord. Moreover, it was evidenced that the stimulation of the descending noradrenergic system could lead to the activation of spinal $\mathrm{a}_{2}$-adrenoceptor and antinociception [30,31]. Abubakar et al have reported that the three $\mathrm{a}_{2}$-adrenoceptor subtypes can act as presynaptic inhibitory feedback receptors to control the release of catecholamines from adrenergic neurons. Therefore, they are linked to the antinociceptive process [32]. In this study, the pretreatment of mice with yohimbine ( $\mathrm{a}_{2}$-adrenergic receptor antagonist) significantly reduced the antinociceptive activity of syringic acid. This fact could demonstrate that spinal and supraspinal mediated $\mathrm{a}_{2^{-}}$ adrenergic receptor plays a significant role in its antinociceptive activity.

Furthermore, naloxone has been recommended for the determination of receptor affinity of typeselective opioids in mammals. Nonetheless, naloxone seems to preferentially interact with $\mu$ binding sites. Moreover, naloxone presents a significant affinity for $\mathrm{\kappa}$ opioid receptors and less affinity for $\delta$ opioid receptors [33]. The activation of even one of the aforementioned opioid receptors by periaqueductal gray area via the administration of beta-endorphin, morphine, or other opioids provokes potent antinociception at supraspinal sites. In addition, it activates the descending pain control pathways, which have been reported to be mediated by the brainstem rostral ventromedial medulla [34]. In further, naloxone reverted the antinociceptive activity of syringic acid in both hot-plate and tail-flick assays. Therefore, the obtained data reveal that the opioid receptors can play a significant role in the spinal and supraspinal mediated antinociceptive effect of syringic acid.

Dalmagro et al. reported that syringic acid can resist the provoked-glutamate casualty in the cortical and hippocampal slices revealing the involvement of the neuroprotection in the antidepressant-like activity [35]. Glutamate is the major excitatory neurotransmitter in the central neural system; it involves the processes of nociceptive transmission, development, and maintenance of the nociceptive response via the ionotropic (iGLURs) and metabotropic (mGLURs) receptors. This fact may result in the excitation and sensitization of peripheral, central spinal, and/or supraspinal nociceptors [36,37]. Besides, previously researched have claimed that glutamate receptors could play a role in syringic acid-induced antinociception [38]. Additionally, syringic acid significantly decreased dopamine levels; the syringic acid induced dopamine levels of the hippocampus can facilitate recognition and short-term memory through the activation of dopaminergic receptors or pathways [39]. According to a recent study, $\mathrm{D}_{1}$ - and $\mathrm{D}_{2}$-like dopamine receptors are importantly involved in antinociceptive responses induced by chemical stimulation of the lateral hypothalamus [40]. Subsequently, it can be assumed that the hypothalamus-mediated dopaminergic pathway could be contributed to the antinociceptive activity of syringic acid.

\section{CONCLUSION}

Based on the results retrieved from the present investigation, it was summarized that syringic acid possesses analgesic and antinociceptive properties. This rich in phenols compound can therefore potentially applied in pain management applications and open up a new window for pain relief. The antinociceptive effect of syringic acid can be measured in a dose-dependent manner. It can be said that future studies would be needed in order to establish the mechanism of the observed actions. Herewith, it was introduced new assumptions to show that syringic acid as a potential analgesic agent which may be further evaluated to improve pain therapy. 


\section{MATERIALS AND METHODS}

\subsection{Chemicals and materials}

Syringic acid was purchased from Cayman Chemical Company, USA. Tween 80, yohimbine hydrochloride, diclofenac sodium, ketanserin tartrate, mecamylamine hydrochloride, naloxone hydrochloride, atropine sulfate, prazosin, and ondansetron were purchased from Sigma, Germany. Each chemical compound or solvents used, were of analytical grade, if not otherwise stated.

\subsection{Animals}

For the current study, adult male BALB/c mice with 20-30g in weight were used. All mice were kept at $20-25^{\circ} \mathrm{C}$ with $12 \mathrm{~h}$ light/dark cycles and $55 \pm 15 \%$ relative humidity. The acclimation of animals at these conditions was done at least 7 days before the initiation of dosing; mice were given ad libitum access to food and water. In further, the mice fasted for a fixed period (e.g., overnight) before the nociception tests. The analysis assays were done between 8.00 and $12.00 \mathrm{a}$.m. They were only given water during the six hours prior to the experimental procedures, in order to prevent any food interactions of food with syringic acid. The experimental procedures were carried out in compliance with the recommendations of the National Institute of Health Guide for the Care and Use of Laboratory Animals and were accepted by the Medipol University Ethical committee. The procedure was taken place with extra care and concern (Approval no: 2020-67).

\subsection{Drugs and pharmacological procedures}

The animals were randomly divided into 17; each experimental group consisted of 6 mice. The control group received only solvent vehicle. As a reference drug, Diclofenac $(25 \mathrm{mg} / \mathrm{kg})$ was orally administrated [41]. In further, syringic acid was also orally administered (Tween $80(\% 1, \mathrm{v} / \mathrm{v})$ ) at the doses of 10, 50, and $100 \mathrm{mg} / \mathrm{kg}$. Moreover, intraperitoneal injections of the used antagonists were chosen.

The action mechanisms were investigated by pre-treating the mice with muscarinic receptor antagonist - atropine $(5 \mathrm{mg} / \mathrm{kg})$, nicotinic receptor antagonist - mecamylamine $(1 \mathrm{mg} / \mathrm{kg})$, serotonin $5-\mathrm{HT}_{2 \mathrm{~A} / 2 \mathrm{C}}$ receptor antagonist - ketanserin $(1 \mathrm{mg} / \mathrm{kg})$, serotonin $5-\mathrm{HT}_{3}$ receptor antagonist - ondansetron $(1 \mathrm{mg} / \mathrm{kg}), \mathrm{a}_{2^{-}}$ adrenoceptor antagonist - yohimbine $(1 \mathrm{mg} / \mathrm{kg}), \mathrm{a}_{1}$-adrenoceptor antagonist - prazosin $(1 \mathrm{mg} / \mathrm{kg})$, and opioid antagonist - naloxone $(1 \mathrm{mg} / \mathrm{kg})$, at 20,30, 30, 30, 30 and $15 \mathrm{~min}$ before the administration of Syringic acid, respectively. Before any combination studies were conducted, the antinociceptive effect of the antagonist agents when administered alone was examined in the mouse hot-plate and tail-flick assay.

Hot-plate and tail-flick tests (60 min after syringic acid administration) were performed in order to measure the pain threshold. The antagonist doses were chosen based on the efficacies demonstrated in previous investigations of these receptors. The antagonist/drug doses and administration schedules were chosen according to previous reports [38,42,43].

\subsection{Pharmacological tests}

\subsubsection{Hot-plate test}

A hot-plate test was applied in order to examine the antinociceptive effect of syringic acid. The choice of animals for the hot-plate test was based on their response time of up to $15 \mathrm{~s}$ such as to thermal stress. The animal selection was done the previous day of the experiment. A hot-plate analgesia meter was utilized to measure the pain reflexes in response to thermal stimuli (Ugo Basile Instruments, Comerio, Italy). The mice from each party were put on the pre-heated plate $\left(55 \pm 0.5^{\circ} \mathrm{C}\right)$. As reaction time was taken the latency of licking or flicking its hind paw or jumping upward. The 20s were chosen as cut-off time in order to minimize hind paw damage. Finally, the mice behavior was recorded before treatment and after treatment [44].

\subsubsection{Tail-flick test}

A tail-flick unit (Ugo Basile, Italy) was used in order to obtain the tail-flick latency; the kit consisted of an infrared radiant light source $(100 \mathrm{~W}, 15 \mathrm{~V}$ bulb) centered on a photocell using a parabolic mirror. Leather gloves have been used to gently handle rodents, throughout the experimental procedures. The radiant heat was localized $3 \mathrm{~cm}$ from the distal tip, and the time taken for the tail to flick or twitch was recorded (tail-flick time). The test was stopped if the latency exceeded over 15s (cut-off time) [45].

The obtained data from the hot-plate and tail-flick experiments were given as a percentage of the maximal possible effect (MPE\%) using the following Equation 1. The percentage was calculated via response latency against thermal stimulus: 


\subsection{Statistical analysis}

The statistical analyses were performed with GraphPad Prism 7.0 software, Inc., San Diego, CA. The representation of the results was recorded as mean \pm SEM. In further, the analysis of the data was done with a one-way analysis of variance followed by post hoc (Tukey's) analysis. The $p$ value of less than 0.05 was considered statistically significant.

Author contributions: Concept - M.E.O.; Design - M.E.O.; Supervision - M.E.O.; Resources - M.E.O., A.A.Ş.; Materials - M.E.O., A.A.Ş.; Data Collection and/or Processing - M.E.O., A.A.Ş.; Analysis and/or Interpretation - M.E.O.; Literature Search - M.E.O., A.A.Ş.; Writing - M.E.O.; Critical Reviews - M.E.O., A.A.Ş.

Conflict of interest statement: The authors declared no conflict of interest.

Ethics committee approval: All experiments conducted in this study were approved by ethics committee of Istanbul Medipol University with the approval number of 2020-67 on 2020.

\section{REFERENCES}

[1] Sneddon LU. Evolution of Nociception and Pain: Evidence From Fish Models. Philos. Trans R Soc B Biol Sci. 2019; 374: 20190290. [CrossRef]

[2] Sneddon LU, Elwood RW, Adamo SA, Leach MC. Defining and Assessing Animal Pain. Anim Behav. 2014; 97: 201212. [CrossRef]

[3] van Rensburg R, Reuter H. An Overview of Analgesics: NSAIDs, Paracetamol, and Topical Analgesics Part 1. South African Fam Pract. 2019; 61: S4-S10. [CrossRef]

[4] Cregg R, Russo G, Gubbay A, Branford R, Sato H. Pharmacogenetics of Analgesic Drugs. Br J Pain. 2013; 7(4): 189_ 208. [CrossRef]

[5] Power I. An Update on Analgesics. Br J Anaesth. 2011; 107: 19-24. [CrossRef]

[6] Peterson NC, Nunamaker EA, Turner PV. To Treat or Not to Treat: The Effects of Pain on Experimental Parameters. Comp Med. 2017; 67: 469-482.

[7] Hooijmans CR, Draper D, Ergün M, Scheffe GJ. The Effect of Analgesics on Stimulus Evoked Pain-like Behaviour in Animal Models for Chemotherapy Induced Peripheral Neuropathy- A Meta-Analysis. Sci Rep. 2019; 9: 17549. [CrossRef]

[8] Suokas AK, Sagar DR, Mapp PI, Chapman V, Walsh DA. Design, Study Quality and Evidence of Analgesic Efficacy in Studies of Drugs in Models of OA Pain: A Systematic Review And A Meta-Analysis. Osteoarthr Cartil. 2014; 22(9): 1207-1223. [CrossRef]

[9] Frias B, Merighi A. Capsaicin, Nociception and Pain. Molecules. 2016; 21(6): 797. [CrossRef]

[10] Dubin AE, Patapoutian A. Nociceptors: The Sensors of The Pain Pathway. J Clin Invest. 2010; 120(11): 3760-3772. [CrossRef]

[11] Price DD, Dubner R. Mechanisms of First and Second Pain in The Peripheral and Central Nervous Systems. J Invest Dermatol. 1977; 69: 167-171. [CrossRef]

[12] Mitsi V, Zachariou V. Modulation of Pain, Nociception, and Analgesia by The Brain Reward Center. Neuroscience. 2016; 338: 81-92. [CrossRef]

[13] Falk S, Dickenson AH. Pain and Nociception: Mechanisms of Cancer-Induced Bone Pain. J Clin Oncol. 2014; 32: 16471654. [CrossRef]

[14] Tracey WD Jr. Nociception. Curr Biol. 2017; 27(4): R129-R133. [CrossRef]

[15] Srinivasulu C, Ramgopal M, Ramanjaneyulu G, Anuradha CM, Kumar CS. Syringic acid (SA) - A Review of Its Occurrence, Biosynthesis, Pharmacological and Industrial Importance. Biomed Pharmacother. 2018; 108: 547-557. [CrossRef]

[16] Ramachandran V, Raja B. Protective Effects of Syringic Acid Against Acetaminophen-Induced Hepatic Damage in Albino Rats. J Basic Clin Physiol Pharmacol. 2010; 21: 369-386. [CrossRef] 
[17] Ren J, Yang M, Xu F, Chen J, Ma S. Acceleration of Wound Healing Activity with Syringic Acid in Streptozotocin Induced Diabetic Rats. Life Sci. 2019; 233: 116728. [CrossRef]

[18] Gias ZT, Afsana F, Debnath P, Alam MS, Ena TN, Hossain MH, et al. A Mechanistic Approach to HPLC Analysis, Antinociceptive, Anti-inflammatory and Postoperative Analgesic Activities of Panch Phoron in Mice. BMC Complement Med Ther. 2020; 20: 102. [CrossRef]

[19] Bouhlali EDT, Hmidani A, Bourkhis B, Khouya T, Ramchoun M, Filali-Zegzouti Y, et al. Phenolic Profile and Antiinflammatory Activity of Four Moroccan Date (Phoenix Dactylifera L.) Seed Varieties. Heliyon. 2020; 6: e03436. [CrossRef]

[20] Cikman O, Soylemez O, Ozkan OF, Kiraz HA, Sayar I, Ademoglu S, et al. Antioxidant Activity of Syringic Acid Prevents Oxidative Stress in L-arginine-Induced Acute Pancreatitis: An Experimental Study on Rats. Int Surg. 2015; 100: 891-896. [CrossRef]

[21] Choi J, Shin K-M, Park H-J, Jung H-J, Kim H-J, Lee YS, et al. Anti-Inflammatory and Antinociceptive Effects of Sinapyl Alcohol and its Glucoside Syringin. Planta Med. 2004; 70: 1027-1032. [CrossRef]

[22] Giorno TBS, Moreira IGDS, Rezende CM, Fernandes PD. New $\beta$ N-octadecanoyl-5-hydroxytryptamide: Antinociceptive Effect and Possible Mechanism of Action in Mice. Sci Rep. 2018; 8: 10027. [CrossRef]

[23] Mirza AC, Panchal SS. Safety Evaluation of Syringic Acid: Subacute Oral Toxicity Studies in Wistar Rats. Heliyon. 2019; 5: e02129. [CrossRef]

[24] Oliveira PA, Capim SL, Gonçalves GM, Laureano-Melo R, Côrtes WDS, Vasconcellos MLAA, et al. Pharmacological Evaluation Underlying The Antinociceptive Activity of Two New Hybrids NSAIDs Tetrahydropyran Derivatives. Fundam Clin Pharmacol. 2020; 34: 321-335. [CrossRef]

[25] Fiorino DF, Garcia-Guzman M. Muscarinic Pain Pharmacology: Realizing The Promise of Novel Analgesics by Overcoming Old Challenges. Handb Exp Pharmacol. 2012; 208: 191-221. [CrossRef]

[26] Vincler M. Neuronal Nicotinic Receptors as Targets for Novel Analgesics. Expert Opin Investig Drugs.2005; 14(10): 1191-1198. [CrossRef]

[27] Sudo RT, Hayashida K, Santos AN, Kawatani M, Monteiro CE, Moreira RD, et al. Novel Agonist of a $4 \beta 2$ * Neuronal Nicotinic Receptor with Antinociceptive Efficacy in Rodent Models of Acute and Chronic Pain. J Pain Res. 2018; 11: 2453-2462. [CrossRef]

[28] Woodcock J, Witter J, Dionne RA. Stimulating The Development of Mechanism-Based, Individualized Pain Therapies. Nat Rev Drug Discov. 2007; 6: 703-710. [CrossRef]

[29] Llorca-Torralba M, Borges G, Neto F, Mico JA, Berrocoso E. Noradrenergic Locus Coeruleus Pathways in Pain Modulation. Neuroscience. 2016; 338: 93-113. [CrossRef]

[30] Tanabe M, Takasu K, Kasuya N, Shimizu S, Honda M, Ono H. Role of Descending Noradrenergic System and Spinal a2-adrenergic Receptors in The Effects of Gabapentin on Thermal and Mechanical Nociception After Partial Nerve Injury in The Mouse. Br J Pharmacol. 2005; 144: 703-714. [CrossRef]

[31] Gutierrez T, Nackley AG, Neely MH, Freeman KG, Edwards GL, Hohmann AG. Effects of Neurotoxic Destruction of Descending Noradrenergic Pathways on Cannabinoid Antinociception in Models of Acute and Tonic Nociception. Brain Res. 2003; 987: 176-185. [CrossRef]

[32] Abubakar A, Nazifi AB, Odoma S, Shehu S, Danjuma NM. Antinociceptive Activity of Methanol Extract of Chlorophytum Alismifolium Tubers in Murine Model of Pain: Possible Involvement of a2-adrenergic Receptor and KATP Channels. J Tradit Complement Med. 2020; 10: 1-6. [CrossRef]

[33] Romero TRL, Pacheco DDF, Duarte IDG. Xylazine Induced Central Antinociception Mediated by Endogenous Opioids and $\mu$-opioid Receptor, But Not $\delta$-or K-opioid Receptors. Brain Res. 2013; 1506: 58-63. [CrossRef]

[34] Pavlovic ZW, Bodnar RJ. Opioid Supraspinal Analgesic Synergy Between The Amygdala and Periaqueductal Gray in Rats. Brain Res. 1998; 779: 158-169. [CrossRef]

[35] Dalmagro AP, Camargo A, Severo Rodrigues AL, Zeni ALB. Involvement of PI3K/Akt/GSK-3 $\beta$ Signaling Pathway in The Antidepressant-like and Neuroprotective Effects of Morus Nigra and Its Major Phenolic, Syringic acid. Chem Biol Interact. 2019; 314: 108843. [CrossRef]

[36] Martini LH, Jung F, Soares FA, Rotta LN, Vendite DA, Frizzo ME, et al. Naturally Occurring Compounds Affect Glutamatergic Neurotransmission in Rat Brain. Neurochem Res. 2007; 32: 1950-1956. [CrossRef]

[37] Ismail NI, Ming-Tatt L, Lajis N, Akhtar MN, Akira A, Perimal EK, et al. Antinociceptive Effect of 3-(2,3dimethoxyphenyl)-1-(5-methylfuran-2-yl)prop-2-en-1-one in Mice Models of Induced Nociception. Molecules. 2016; 


\section{1: 1077. [CrossRef]}

[38] Dalmagro AP, Camargo A, Zeni ALB. Morus Nigra and Its Major Phenolic, Syringic Acid, Have Antidepressant-Like and Neuroprotective Effects In Mice. Metab Brain Dis. 2017; 32: 1963-1973. [CrossRef]

[39] Ogut E, Akcay G, Yildirim FB, Derin N, Aslan M. The Influence of Syringic Acid Treatment on Total Dopamine Levels of The Hippocampus and on Cognitive Behavioral Skills. Int J Neurosci. 2020; 17: 1-9. [CrossRef]

[40] Rezaee L, Alizadeh AM, Haghparast A. Role of Hippocampal Dopamine Receptors in The Antinociceptive Responses Induced by Chemical Stimulation of The Lateral Hypothalamus in Animal Model of Acute Pain. Brain Res. 2020; 1734: 146759. [CrossRef]

[41] Ahmed F, Shahid IZ, Biswas UK, Roy BA, Das AK, Choudhuri MSK. Anti-inflammatory, Antinociceptive, and Neuropharmacological Activities of Clerodendron Viscosum. Pharm Biol. 2007; 45: 587-593. [CrossRef]

[42] Bektaş N, Arslan R. The Centrally-Mediated Mechanisms of Action of Ferulic Acid-Induced Antinociception. Marmara Pharm J. 2016; 20: 303-310.

[43] Arslan R, Bektas N. Evaluation of the Centrally-Acting Mechanisms of Some Non-Steroidal Anti-inflammatory Drugs. Am J Pharm Heal Res. 2015; 3: 191-202.

[44] Arslan R, Aydin S, Nemutlu Samur D, Bektas N. The Possible Mechanisms of Protocatechuic Acid-induced Central Analgesia. Saudi Pharm J. 2018; 26: 541-545. [CrossRef]

[45] De Caro C, Raucci F, Saviano A, Cristiano C, Casillo GM, Di Lorenzo R, et al. Pharmacological and Molecular Docking Assessment of Cryptotanshinone as Natural-Derived Analgesic Compound. Biomed Pharmacother. 2020; 126: 110042. [CrossRef]

This is an open access article which is publicly available on our journal's website under Institutional Repository at http://dspace.marmara.edu.tr. 